\title{
Ambon Banana-Tree Sap stimulated Endothelial Cell Migration in Human Umbilical Vein Endothelial Cells (HUVECs) Induced with Inflammatory Mediator IL-1
}

\author{
Provisia Marthalita Yuning Wulan ${ }^{1 *}$, Maria Juliana Dorothy ${ }^{2}$, Resha Alinda ${ }^{2}$, Kristianingrum Dian \\ Sofiana ${ }^{1}$, Bunga Prihardina ${ }^{1}$, Nur Permatasari ${ }^{3}$, Moch. Aris Widodo ${ }^{4}$ \\ ${ }^{1}$ Department of Biomedical Sciences, Faculty of Medicine, Brawijaya University, Malang 65145, Indonesia \\ ${ }^{2}$ Faculty of Medicine, Brawijaya University, Malang 65145, Indonesia \\ ${ }^{3}$ Faculty of Dentistry, Brawijaya University, Malang 65145, Indonesia \\ ${ }^{4}$ Department of Pharmacology, Faculty of Medicine, Brawijaya University, Malang 65145, Indonesia
}

Article history:

Submission April 2018

Revised July 2018

Accepted September 2018

*Corresponding author:

E-mail: wulanprovisia@yahoo.co.id

\begin{abstract}
Ambon banana-tree (Musa paradisiaca var.sapientum) sap (ABT sap) contains active substances that can stimulate the wound healing process such as: flavonoid, saponin, ascorbic acid. Those substances are needed in an important phase of wound healing called angiogenesis through activation of Vascular Endothelial Growth Factor (VEGF) pathway that stimulates actin reorganization in endothelial cell migration and proliferation. The aim of this study is to evaluate the effectiveness of banana-tree sap in stimulating cells migration, VEGF and nitric oxide (NO) level in Human Umbilical Vein Endothelial Cells (HUVECs) culture that induced by pro-inflammatory cytokine IL-1 (Interleukin-1). The ABT sap was obtained by pressing a fresh Ambon banana stem, then was mixed with culture medium into $0.125 \%, 0.25 \%$ and $0.5 \%$ concentration. The ABT sap then was used for treating HUVECs cell that induced by IL-1 $200 \mathrm{ng} / \mathrm{mL}$ for 48-hours. The result of this study shows that Ambon banana-tree sap increased HUVECs cell migration. However, after 48-hours treatment with ABT sap showed no difference in the VEGF and NO level in the culture media. These results suggested ABT sap able to increase migration to HUVECs that promising for wound healing agent. Therefore, the further research to elucidate the detailed mechanism and identify the active compound warrant to be done.
\end{abstract}

Keywords: Banana Tree Sap, Wound Healing, Cell Migration, VEGF, NO

\section{Introduction}

Ambon banana tree (Musa paradisiaca var. sapientum) is proved to be effective in accelerating the wound healing process. The sap of the Ambon banana tree has shown satisfactory results in the research of the wound healing process in rats (Ratus norvegicus) in vivo [1]. Also, histologically, it provides aesthetical effects by repairing damaged skin structures without leaving scar tissue and accelerating the new blood vessels formation, connective tissue formation and inflammatory cell infiltration in the wound area [2]. Ambon banana tree typically grows in the tropical area such as in the South East Asia countries. This tree is also known for its capability to be bred and cultivated easily. Ambon banana sap contains active substances such as a flavonoid, saponin, and ascorbic acid. Saponin helps to form new blood vessel in the wound so that it can supply more oxygen and nutrients. Ascorbic Acid (AA) strengthens and accelerates the growth of new connective tissues. Flavonoid reduces the duration of inflammation that can inhibit the healing process [3A previous research about Ambon banana stem conclude that it can accelerate the wound healing process with several activities. Those activities inclu- 
de affecting in inflammatory cells, reepithelization, and angiogenesis [4]. This is because the active substances act well as the antioxidants that are capable to reduce superoxide radicals and metals binding. The antioxidants also become the antibacterial and enhance Vascular Endothelial Growth Factor (VEGF) catch signaling pathways through the dimerization of VEGF-R [5].

The angiogenesis phase in the wound healing process is led by growth factors that are secreted by inflammatory cells and other cells in response to tissue injury. Growth factor that plays an important role in the process of angiogenesis in this research is VEGF that acts as an endothelial cell mitogen, a chemotactic agent and the inducer of endothelial cell wall permeability [6]. VEGFR2 becomes the master regulator of endothelial cell function. The activation of VEGFR2 initiates multiple signaling pathways that regulate endothelial proliferation, migration, adhesion and survival [7]. Phosphorylation of VEGFR2 also activates the Raf-MEK-ERK signaling cascade where ERK1/2 phosphorylation induces endothelial cell proliferation, network formation, and increases vessel lumen size [8]. Based on the background, it is necessary to conduct further research on the effectiveness of Ambon banana tree ( $M$. paradisiaca var. sapientum) to accelerate the process of wound healing in vitro by analyzing levels of VEGF, nitric oxide (NO), and endothelial cell migration in Human Umbilical Vein Endothelial Cells (HUVECs) culture which is induced by inflammatory mediators.

\section{Material and Methods \\ Isolation and HUVECs culture}

Umbilicus was collected from cesarean section (CS) procedure with inclusion criteria (normal mother, $\mathrm{HB}<11$, healthy infant (body weight $>2.5 \mathrm{~kg}$, Apgar score $7-9$ )) and exclusion criteria (mother with hypertension, diabetes, cardiovascular disease, pre-eclampsia, and hyperlipidemia). The umbilical cord was incubated $\left(37^{\circ} \mathrm{C}, 8\right.$ minutes) in type 2 collagenase (Sigma) to isolate the endothelial cells. The cells were placed in culture medium containing $100 \mathrm{IU} / \mathrm{mL}$ M199 (Sigma), $100 \mu \mathrm{g} / \mathrm{mL}$ Penicillin, streptomycin (Gibco) and 10\% FBS (Gibco 26140-087). Then, the cells were cultured in 48 wells plate containing $0.2 \%$ gelatin (Sigma G1393) and incubated at $37^{\circ} \mathrm{C}, 5 \% \mathrm{CO}_{2}$. The cells then set aside until it be- came monolayer and confluent about $70-80 \%$ within $3-4$ days. HUVECs were treated by adding IL-1 $200 \mathrm{ng} / \mathrm{mL}$ for the treatment group and incubated for 12 hours. Then, the Ambon Banana saps concentration $0.125 \%, 0.25 \%$ and $0.5 \%$ were added to treatment groups and observed until 48hours. This study was approved by the Ethics Committee of Faculty of Medicine Brawijaya University (No. 202/EC/KEPK/06/2017) Malang, Indonesia.

\section{Ambon banana-tree sap collection}

The 1-year-old of Ambon banana tree (M. paradisiaca var. sapientum) used in this research was taken from Lumajang with the local tropic temperature at around $27-30^{\circ} \mathrm{C}$ and rainfall rate around $1,400-2,450 \mathrm{~mm} / \mathrm{year}$. The tree was cut in diagonal section, then taken only $250 \mathrm{~g}$ of the tree. After that, it was pressed to collect the liquid from the tree and gathered into a sterile bottle that is closed with aluminum foil paper to avoid oxidation process. The bottle was saved at a temperature around $15-25^{\circ} \mathrm{C}$. Before the sap was added to the culture media, the $\mathrm{pH}$ was checked until it reached around 7 and strained in filter $0.2 \mu \mathrm{m}$.

\section{ELISA for VEGF}

Enzyme-Linked Immuno Sorbent Assay (ELISA) (Human-VEGF-ELISA kit, Bioassay Technology, China) was used to measure VEGF in the medium. Micro-plates (96 wells) were filled with sample solution $40 \mu \mathrm{L}$ and anti-VEGF antibody $10 \mu \mathrm{L}$. All wells were added with SA-HRP $50 \mu \mathrm{L}$, closed with adhesive cover foil and shaken at $37^{\circ} \mathrm{C}$ for 60 minutes. After that, the washing process was repeated 5 times using a washing buffer. Then, $50 \mu \mathrm{L}$ of substrate solution A and 50 $\mu \mathrm{L}$ of substrate solution B were added into the wells and shake in dark conditions before they were incubated at $37^{\circ} \mathrm{C}$ for 10 minutes. Then, 50 $\mu \mathrm{L}$ of stop solution was added in the wells. The absorptions were measured with the ELISA reader to know the number of VEGF in the medium at a wavelength of $450 \mathrm{~nm}$.

\section{Migration (wound healing assay)}

A confluent cell in the wells was scratched with $1 \mathrm{~mm}$ yellow tip (200 $\mu \mathrm{L}$ size tip) in order to represent a wound (Scratch/Wound Healing Assay). The width of the scratch $(1 \mathrm{~mm}$ free cell zone) was measured in $0,12,24$ and 48 hours to 
a

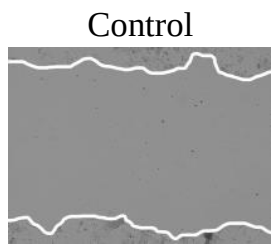

b
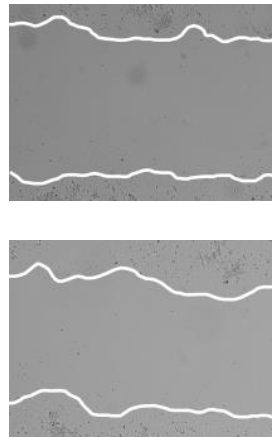

d

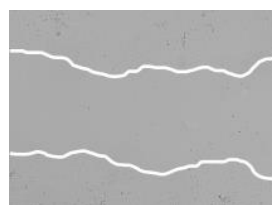

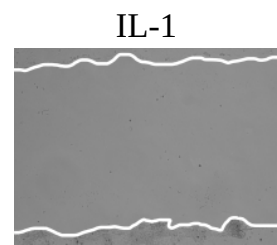
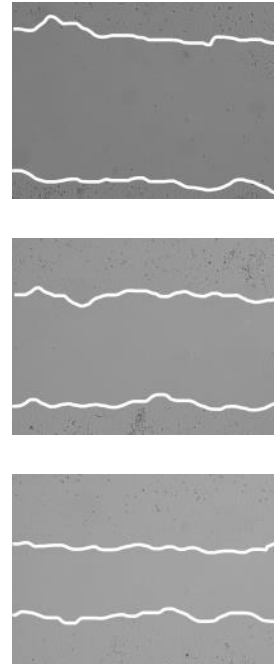
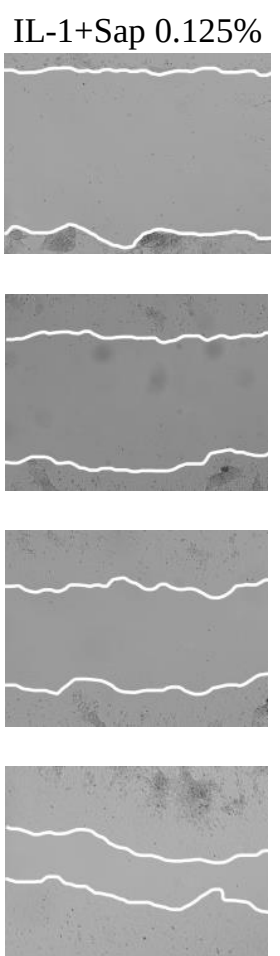
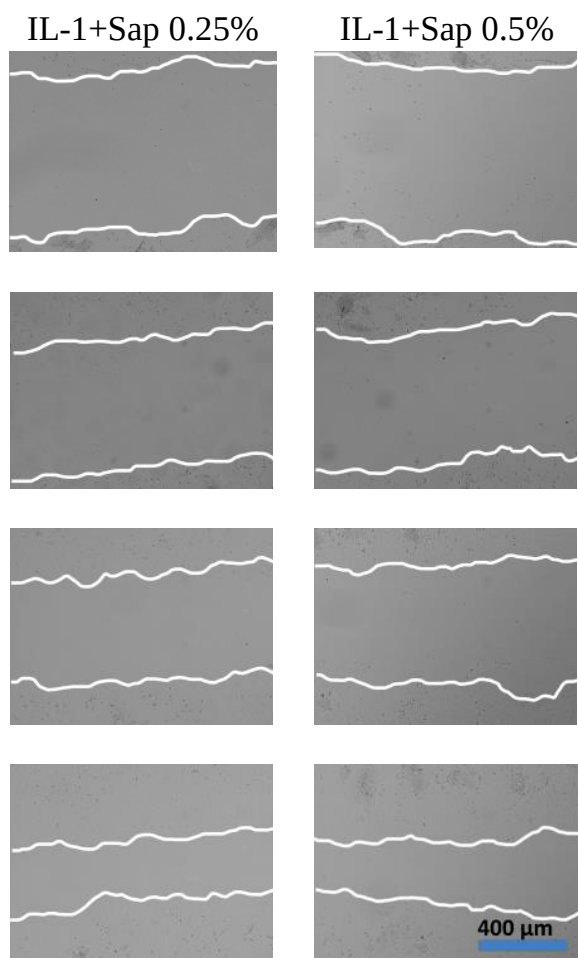

Figure 1. Migration of endothelial cells in a various group of treatments, after scratched with a yellow tip (200 $\mu \mathrm{L}$ ) for about $1 \mathrm{~mm}$ free zone of the cell in the plate (a), after 12 hours (b), 24 hours (c), and 48 hours (d).

know the migration percentage (\%). The migration was measured with formula [9]:

$\%$ Migration of HUVECs $=100-\left(\left[\frac{x}{y}\right] \times 100\right) \%$

Note:

$\mathrm{x}$ : the free cell zone after treatment

$\mathrm{y}$ : the free cell zone before treatment

\section{NO level}

NO levels were determined by harvesting the HUVECs culture medium and performing Griess reaction with NO Assay kit colorimetric (Cayman Chemical, USA). NO densities in each well were read at a wavelength of $550 \mathrm{~nm}$ using a spectrophotometer (BMG Lab Tech, Germany).

\section{Data analysis}

The data analysis was performed using SPSS 23 version software for Windows (IBM Corporation, USA). The data were analyzed using One Way ANOVA in order to examine the significance of each group $(\mathrm{p}<0.05)$.

\section{Results and Discussion}

\section{The Effect of Ambon banana-tree sap on endo- thelial cell migration}

The Ambon banana-tree sap can recover the cell migration and accelerate the endothelial cell migration $(p=0.001)$. The result shows that IL-1 $200 \mathrm{ng} / \mathrm{mL}$ induction can decrease the cell migration (Figure 1). After 24 hours, the ABT sap shows the significant effect in the recovery process and make the migration faster than the control group. In 48 hours, the ABT sap has brought the free cell zone closer than the control group. This means that the ABT sap can increase the migration of endothelial cells.

After the scratch treatment, HUVECs were observed in 12 hours and the result shows that IL-1 $200 \mathrm{ng} / \mathrm{mL}$ induction decreased cell migration because IL-1 acts as an inflammatory mediator. The highest migration in 12 hours is in the control group, and the lowest is IL-1 induced group. After 24 hours, the ABT sap shows the significant effect in recovery and makes the migration faster than the control group. In 48 hours, the ABT sap has brought the free cell zone closer than the control group. This means that ABT sap can increase the migration of endothelial cells. IL-1 decreases the 


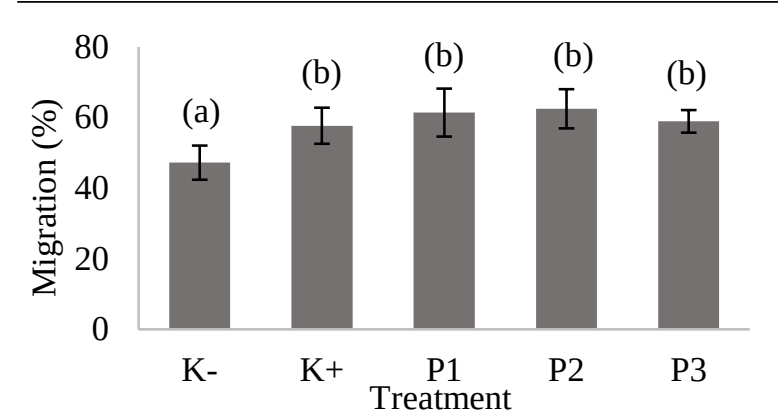

Figure 2. The Ambon banana sap treatment induced migration faster compared to the control ( $p$ $=0.001)$. The lowest migration is in the control group and the highest migration is in the treatment group (0.25\%). (a) is significantly different with (b). (Note: $\mathrm{K}-=$ control, $\mathrm{K}+$ + IL-1, P1 = IL-1 + SAP 0.125\%, P2 = $\mathrm{IL}-1+\mathrm{SAP} 0.25 \%$ and P3 = IL-1 + SAP $0.5 \%$

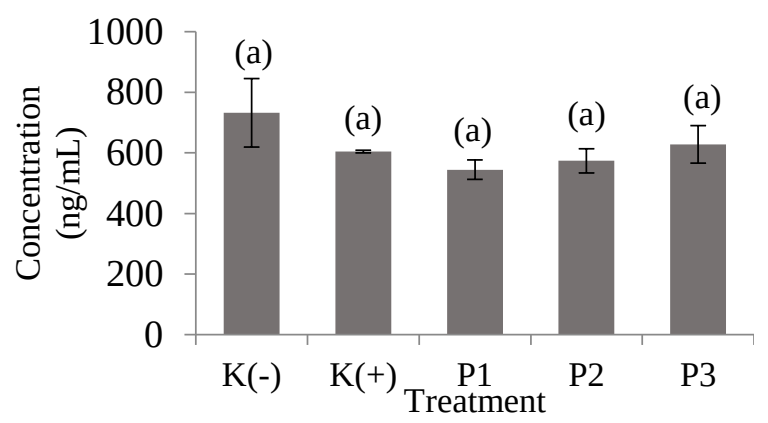

Figure 3. The concentration of VEGF in 48 hours was almost similar in all groups, however the control groups showed higher than other groups event statistically not significant $(\mathrm{p}=$ 0.054). (Note: $\mathrm{K}-=$ control, $\mathrm{K}++\mathrm{IL}-1, \mathrm{P} 1=$ IL-1 + SAP 0.125\%, P2 = IL-1 + SAP 0.25\% and P3 = IL-1 + SAP 0.5\%)

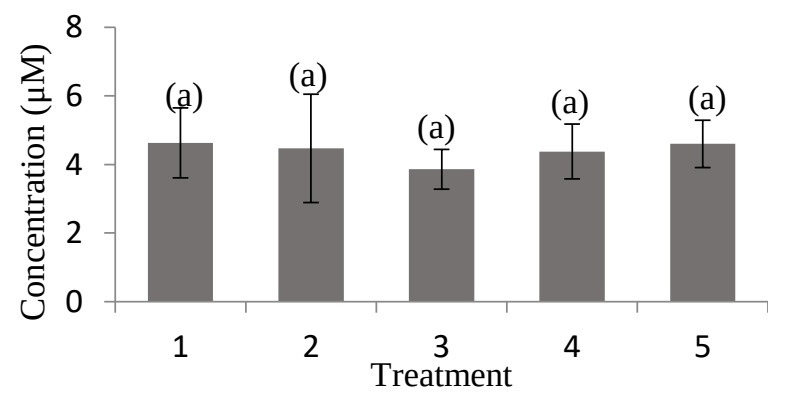

Figure 4. NO levels after 48 hours treatment was not significantly different in among groups ( $\mathrm{p}=$ 0.878). The lowest NO level was present in the low levels of sap treatment, that it is in line with the concentration of VEGF and migration status. (Note: $\mathrm{K}-=$ control, $\mathrm{K}++\mathrm{IL}$ $1, \mathrm{P} 1=\mathrm{IL}-1+\mathrm{SAP} 0.125 \%, \mathrm{P} 2=\mathrm{IL}-1+$ SAP $0.25 \%$ and P3 = IL-1 + SAP 0.5\%) migration for 12 hours and then raises the migration after 12 hours because IL-1 can also stimulate the cell to repair the inflammation after the damage by increasing the NF-kB to transcript pro-inflammatory cytokines. IL-1 activates PI3K and AKT/PKB as well to drive IKK-dependent activation, then produces the pro-angiogenic (VEGF) and pro-inflammatory cytokines [10].

\section{The Effect of Ambon banana-tree sap to VEGF}

The highest concentration of VEGF is in the control group, otherwise a low concentration in the treatment group (Figure 3). It occurred might be caused by the VEGF was decreasing after overexpressed in the earlier time. This was indicated by a higher migration in the sap treatment groups. The VEGF has already finished its role in the migration pathway to trigger cell migration faster, then the VEGF entered the downstream time to give negative feedback after working in the signaling system. After maximizing its role, the decreasing of the VEGF in order to avoid over-proliferate [11].

\section{The Effect of Ambon banana-tree saps to NO}

The highest concentration of NO is in the control group, but the lowest in $0.125 \%$ of Ambon banana sap treated-cell. It might be stimulated by flavonoid form Ambon banana sap that can escalate SOD to be a superoxide scavenger [12]. Ambon banana sap contains many anti-oxidant agents so that it can decrease the ROS to recover the HUVECs inflammation.

According to the data indicated that ABT sap treatment has lowest NO, VEGF and higher cell migration. It could be assumed the ABT sap may have activity as antioxidant, and simulator of cell migration for in the inflammation cell. The HUVACs cell was induced into inflammation by IL-1 and seem recovery after 48 hours treated with ABT sap. Moreover, the ABT sap also able to enhance the cell migration. The data suggested that ABT sap has beneficial for wound healing. Therefore, further research to elucidate the mechanism more detail still warrants to be done.

\section{Conclusion}

Based on the results could be concluded that Ambon banana sap able to stimulate the HUVECs cell migration in vitro. The ABT sap showed no 
significant control VEGF and NO level in the medium after 48 hours treatment in HUVECs cell. Further research to elucidate the mechanism and identify the active compound of Ambon banana sap on the wound healing function still needs to be done.

\section{Acknowledgment}

The authors of this research would like to express our gratitude towards Permata Bunda Hospital for providing us the opportunity to take samples for this research. We are also very grateful to our technical assistants Mr. Wahyuda Ngatiril Lady. This research was also supported by Biomedical Laboratory of Brawijaya University and the Research Development Foundation of Medical Faculty Brawijaya University, Malang, Indonesia.

\section{References}

1. Budi HS, Kriswandini IL, Sudjarwo SA (2016) Ambonese banana stem sap (Musa paradisiaca var.sapientum) effect on PDGF-BB expressions and fibroblast proliferation in soket wound healing. Internaional Journal of ChemTech Research 9 (12): 558 - 564 .

2. Febram B, Wientarsih I, Pontjo B (2010) Activity of Ambon banana (Musa paradisiaca var. sapientum) stem extract in oinment formulation on the wound healing process of mice skin (Mus musculus albinus). Traditional Medicine Journal 15 (3): $121-137$.

3. Yosaphat Bayu R., Juni Handajani, Heni SUsilowati. (2012). Efek pemberian gel getah batang tanaman pisang secara topikal terhadap kepadatan serabut kolagen pada proses penyembuhan luka pasca ekstraksi gigi marmut. Dentika Dental Journal 17 (1): $34-39$.
4. Nugrahenny D, Widodo MA, Permatasari N (2012) Vitamin E mempertahankan kemampuan EPC yang dipapar glukosa tinggi dalam pelepasan NO dan induksi migrasi sel endotel. Jurnal Kedokteran Brawijaya 27 (1): 8 - 15 . doi: 10.21776/ub.jkb.2012.027.01.2.

5. Li Y, Du Y, Zou C (2009) Effect of pH on antioxidant and anti microbial properties of tea saponins. European Food Resources Tecnological 288: 1023 - 1028.doi: 10.1007/s00217-009-10143.

6. Bao P, Kodra A, Tomic-Canic M et al. (2009) The Role of vascular endothelial growth factor in wound healing. Journal of Surgical Research 153 (2): 347 - 358. doi: 10.1016/j.jss.2018.04.023.

7. Koch S, Tugues S, Li X et al. (2011) Signal transduction by vascular endothelial growth factor receptors. The Biochemical Journal 437 (2): 169 - 183. doi: 10.1042/BJ20110301.

8. Lanahan AA, Hermans K, Claes F et al. (2010) VEGF receptor 2 endocytic trafficking regulates arterial morphogenesis. Developmental Cell 18 (5): $713 \quad$ - 724 . doi: 10.1016/j.devcel.2010.02.016.

9. Cahill CM, Rogers JT (2008) Interleukin (IL) 1beta induction of IL-6 is mediated by a novel phosphatidylinositol 3-kinasedependent AKT/IkappaB kinase alpha pathway targeting activator protein-1. Journal of Biological Chemistry 283: 25900 25912. doi: 10.1074/jbc.M707692200.

10. Mei Yang, Juan Zou, Hongmei Zhu, Shanling Liu, He Wang, PengBai, Xue Xiao (2015) Paris saponin II inhibits human ovarian cancer cell-induced angiogenesis by modulating NF-Kb Signaling. Oncology Reports 33 (5): 2190 - 2198. doi: 10.3892/or.2015.3836.

11. Vijayakumar S, Presannakumar G, Vijayalakshmi NR (2009) Investigations on the effect of flavonoids from banana, Musa paradisiaca L. on lipid metabolism in rats. Journal of Dietary Supplements $6 \quad$ (2): $111 \quad$ - $123 . \quad$ doi: $10.1080 / 19390210902861825$ 
This page is intentionally left blank. 